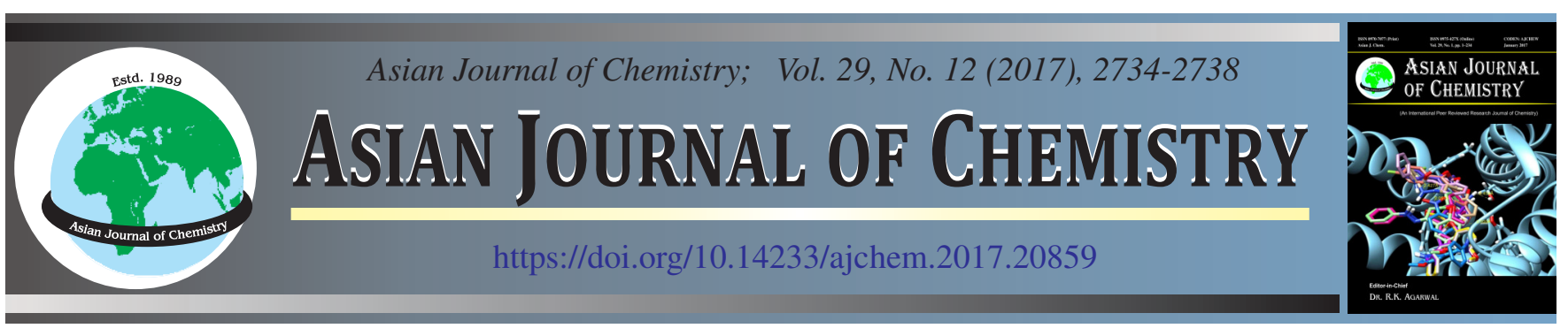

\title{
Modification of Chaetoceros sp. Biomass with Silica-Magnetite Coating and Adsorption Studies towards Cu(II) Ions in Single and Binary System
}

\author{
Buhani ${ }^{*}$, Musrifatun, D.S. Pratama, Suharso and Rinawati
}

Department of Chemistry, Faculty of Mathematics and Natural Sciences, University of Lampung, Jl. Soemantri Brojonegoro No. 1, Bandar Lampung, Indonesia

*Corresponding author: Tel/Fax: + 62721 704625; E-mail: buhani_s@yahoo.co.id

\begin{abstract}
Adsorbent synthesis from Chaetoceros sp. biomass with silica-magnetite coating technique (ASMC) and without magnetite (ASC) has been performed through the sol-gel process. Both adsorbents were characterized by infrared spectrophotometer, X-Ray diffraction and scanning electron microscopy. The adsorption process of $\mathrm{Cu}(\mathrm{II})$ ions was performed in a single and binary systems using batch method. The adsorption data of $\mathrm{Cu}$ (II) ions on ASC and ASMC within a single system follows the pseudo kinetic model of order 2 with the adsorption rate of $\mathrm{Cu}(\mathrm{II})$ ions on ASMC faster than ASC. The adsorption isotherm model of $\mathrm{Cu}$ (II) ions on ASC and ASMC tend to follow Langmuir adsorption isotherm model with adsorption capacity of 57.77 and $105.91 \mathrm{mg} \mathrm{g}^{-1}$, respectively. The ASMC material is not selective for $\mathrm{Cu}(\mathrm{II})$ ions with the ion pairs such as $\mathrm{Ni}(\mathrm{II}), \mathrm{Zn}(\mathrm{II}), \mathrm{Cd}(\mathrm{II})$ and $\mathrm{Pb}(\mathrm{II})$ ions.
\end{abstract}

Keywords: Adsorption capacity, Chaetoceros sp., Silica-magnetite coating, Heavy metals.

\section{INTRODUCTION}

Currently, efforts are processing waste containing heavy metals before being discharged into the environment is likely to increase. One of these efforts is with utilizing of natural materials such as biomass derived from algae, fungi and agricultural waste as heavy metal adsorbent $[1,2]$.

Algal biomass is a natural material that has the ability to absorb heavy metals and has a considerable abundance in the waters. Utilization of algae as heavy metal adsorbent is still not optimal, whereas algae has great capability to bind heavy metals which are one source of environmental pollution. Some studies [3-5] have shown that the algae alive or in the form of biomass can effectively absorb heavy metals. But algae's ability to bind heavy metals is very limited by several problems such as small size, low specific weight and easily damaged due to degradation by other microorganisms [6,7]. In addition, algae cannot be used directly in the adsorption column, because it is very soft and no granular form [8]. To overcome these weaknesses, various attempts were made among others with immobilizing of algae biomass using a variety of support polymers.

Immobilization of algal biomass with a supporting matrix of silica has been done and managed to increase the adsorption capacity of the metal ions $[9,10]$. Enhancement of adsorption selectivity through an ionic imprinting technique on Nannochloropsis sp. biomass has also been performed [11]. Although the material has been obtained modified algae biomass is the best properties, such as high capacity, large adsorption selectivity, and chemically stable. In use as an adsorbent, the material causes problems due to suspended solids formed (flocculants) that inhibit the process of separating metals from solution, consequently the adsorption process is slower and produces by-products in the form of suspended solids that are less environmentally friendly $[12,13]$.

Improving the quality of adsorbent can be done by applying a sol-gel process in the synthesis of algal biomass with a supporting matrix such as silica, because the process can produce homogeneous adsorbent $[14,15]$. Increasing the adsorption rate of metal ions on the adsorbent can be performed using coating technique of magnetite $\left(\mathrm{Fe}_{3} \mathrm{O}_{4}\right)$ particle on silica as a supporting matrix of biomass $[16,17]$. Silica coating technique with magnetite particles are techniques that are environmentally friendly, because it does not form a product containing contaminants such as suspended solids, besides accelerating the process of separation of metals from solutions for magnetic adsorbent $[18,19]$. By using this technique, it will obtain the adsorbent which has a large capacity and selectivity towards target metal ions and can separate target metals quickly [13].

The primary objective of this study is to study the adsorption capacity of the material synthesized algae biomass Chaetoceros sp. (brown algae) by coating silica-magnetite, $\mathrm{Cu}$ (II) ions in the singular and the competition with metal ions such as $\mathrm{Ni}(\mathrm{II})$, 
$\mathrm{Zn}(\mathrm{II}), \mathrm{Cd}(\mathrm{II})$ and $\mathrm{Pb}(\mathrm{II})$ ion as a pair ion (binary system) in the solution.

\section{EXPERIMENTAL}

Synthesis ASC and ASMC: Synthesis of ASMC was done by mixing $5 \mathrm{~mL}$ of TEOS and distilled water into a plastic container, then added $0.1 \mathrm{~g} \mathrm{Fe}_{3} \mathrm{O}_{4}$ [16], with constant stirring for $30 \mathrm{~min}$. When stirring, $0.1 \mathrm{M} \mathrm{HCl}$ was added dropwise until $\mathrm{pH}$ of the solution reached 2 (solution A). In another container, $0.4 \mathrm{~g}$ Chaetoceros sp. biomass blended with ethanol, and then stirred for $30 \mathrm{~min}$ (solution B). Subsequently solution A was mixed with solution B with stirring to form a gel. The gel was formed and then allowed to stand for $24 \mathrm{~h}$. The gel was washed using distilled water and ethanol until the filtrate becomes $\mathrm{pH}$ 7. Then the gel was dried in an oven at $40{ }^{\circ} \mathrm{C}$ to constant weight. The dried material was crushed to 200 mesh size. Synthesis of ASC was performed in the same way as ASMC procedure but without the addition of $\mathrm{Fe}_{3} \mathrm{O}_{4}$.

The materials produced were characterized by IR Prestige21 Shimadzu for identification of functional groups. Obtained crystals were analyzed by XRD (Shimadzu 6000). The surface morphology of material was analyzed by SEM (JSM 6360 LA). Metal ion concentrations were determined using atomic absorption spectrophotometer (AAS) Model Perkins Elmer 3110.

Single system adsorption: The adsorption process was performed to determine, optimum $\mathrm{pH}$, contact time and adsorption isotherm model. Determination of adsorption $\mathrm{pH}$ was determined with interacting $50 \mathrm{mg}$ of adsorbent with $20 \mathrm{~mL}$ of $\mathrm{Cu}$ (II) ion (concentration of $100 \mathrm{mg} \mathrm{L}^{-1}$ ) at varying $\mathrm{pH}$ of 2-8, the solution was added with buffer $\mathrm{CH}_{3} \mathrm{COONa} / \mathrm{HCl}(\mathrm{pH} 3)$ and $\mathrm{CH}_{3} \mathrm{COONa} / \mathrm{CH}_{3} \mathrm{COOH}$ ( $\mathrm{pH} 4-6$ ). The influence of contact time was made by reacting $50 \mathrm{mg}$ of adsorbent in a series of test tube and supplemented with $100 \mathrm{mg} \mathrm{L}^{-1}$ of each $\mathrm{Ni}$ (II) ion solution at $\mathrm{pH}$ optimum with the interaction time varied 0-90 min.

The adsorption isotherms of $\mathrm{Cu}(\mathrm{II})$ ions were studied with interacting $50 \mathrm{mg}$ of adsorbent placed into a series of test tube, then added with a solution of each $\mathrm{Cu}$ (II) ions with varying concentrations of $0-500 \mathrm{mg} \mathrm{L}^{-1}$. The adsorption was done in a batch system using a magnetic stirrer at temperature of $27^{\circ} \mathrm{C}$, optimum $\mathrm{pH}$ and time.

The amount of metal adsorbed per unit mass of adsorbent was calculated as follows:

$$
\mathrm{q}=\mathrm{v}\left(\mathrm{C}_{\mathrm{o}}-\mathrm{C}_{\mathrm{t}}\right) / \mathrm{m}
$$

where $C_{o}$ and $C_{t}\left(\mathrm{mg} \mathrm{L}^{-1}\right)$ is a metal ion concentration before and after the adsorption process, $\mathrm{m}$ is the amount of adsobent (g) and $\mathrm{v}$ is the volume of solution (L).

Binary system adsorption: The amount of $50 \mathrm{mg}$ of adsorbent interacted with $20 \mathrm{~mL}$ of solution containing ion pairs $\mathrm{Cu}(\mathrm{II}) / \mathrm{Ni}(\mathrm{II}), \mathrm{Cu}(\mathrm{II}) / \mathrm{Zn}(\mathrm{II}), \mathrm{Cu}(\mathrm{II}) / \mathrm{Cd}(\mathrm{II})$, and $\mathrm{Cu}(\mathrm{II}) /$ $\mathrm{Pb}$ (II), with each concentration of $0.5 \mathrm{mmol} \mathrm{L}^{-1}$. The adsorption was performed in a batch system using a magnetic stirrer at pH 6 for $60 \mathrm{~min}$.

\section{RESULTS AND DISCUSSION}

The ASMC synthesis was performed through sol-gel process by TEOS hydrolysis followed by mixing magnetite and the addition of algae biomass Chaetoceros sp. in ethanol.
Infrared spectra (Fig. 1c and 1d) show the adsorption patterns which are relatively similar to the silica absorption spectra (Fig. 1b). The addition of new absorption existed in the wave number $2924.09 \mathrm{~cm}^{-1}$ derived from C-H stretching vibration adsorption of $\left(-\mathrm{CH}_{2}\right)$ aliphatic shows that hybridization occured between silica and algae biomass Chaetoceros sp. has been successfully performed in ASC and ASMC. Disappearing of the band at $964.41 \mathrm{~cm}^{-1}$ which is stretching vibration ( $\mathrm{Si}-\mathrm{O}$ ) on ASC and ASMC showed that the completion of the condensation process $[10,11]$.

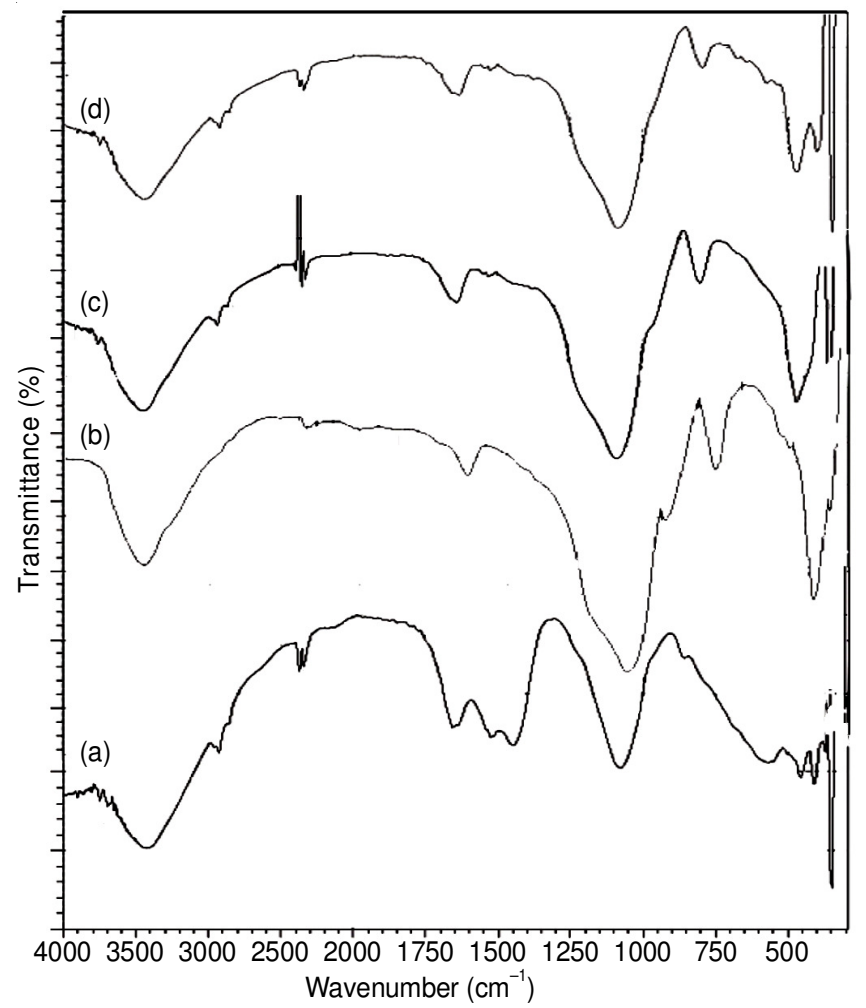

Fig. 1. IR spectra of (a) Chaetoceros sp. algae, (b) silica, (c) ASC and (d) ASMC.

Analysis of the crystal structure of the synthesized material was performed using XRD. Peaks that are contained in the diffractogram then be identified using methods search match methods with file data standard contained in the file PCPDFWIN program 1997 [20,21]. From the analysis, it is known that the diffraction peaks of ASMC (Fig. 2b) are different from the ASC (Fig. 2a). It is also observed that the diffractogram of ASMC has $2 \theta$ as existed on the diffraction peak structure of typical of crystalline $\mathrm{Fe}_{3} \mathrm{O}_{4}$, namely: 35.468; 62.602; 30.133; 57.02021 (Fig. 2b). Based on the analysis, it can be stated that ASC has the structure of a basic form (amorphous) while ASMC indicates magnetite crystals formed (crystoballite).

The analysis results of the surface morphology with SEM (Fig. 3) show the difference between ASC surface morphology (Fig. 3a) and ASMC (Fig. 3b). The surface morphology ASMC looks more contrast than the surface morphology ASC because of the existence of $\mathrm{Fe}_{3} \mathrm{O}_{4}$ particles in the material. The existence $\mathrm{Fe}_{3} \mathrm{O}_{4}$ leads to higher accelerating because it contains high atomic number, resulting in a wide scattering that produces a higher intensity so much contrast. 


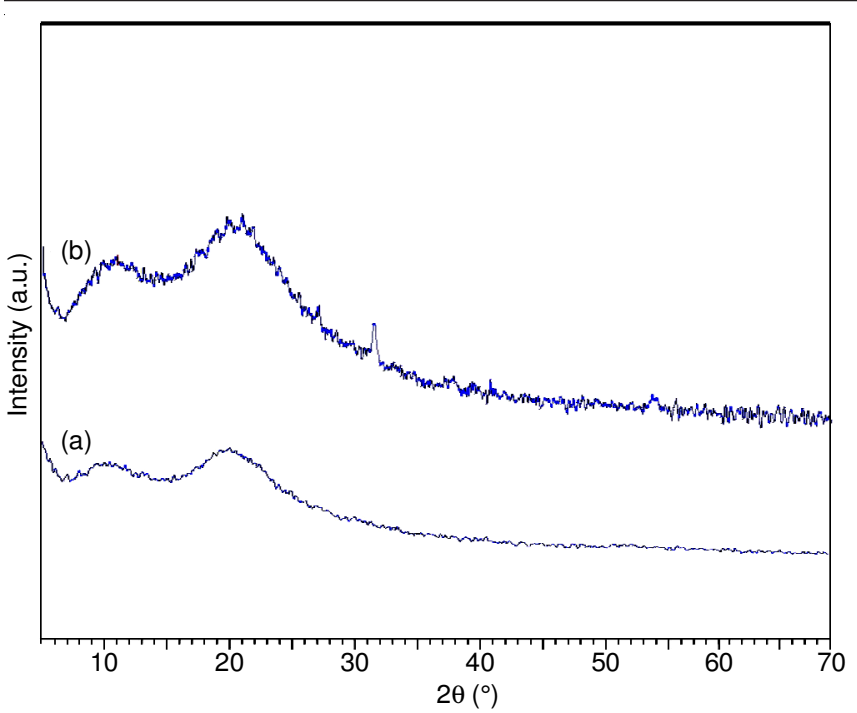

Fig. 2. Typical XRD patterns of (a) ASC and (b) ASMC
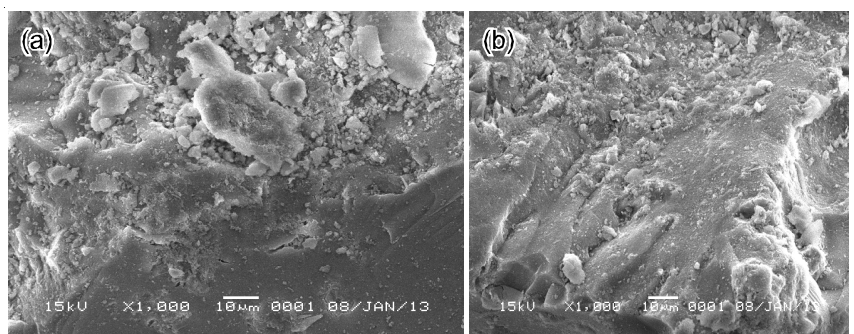

Fig. 3. SEM of (a) ASC and (b) ASMC

Effect of pH: Interaction of $\mathrm{Cu}(\mathrm{II})$ ions with $\mathrm{ASC}$ and ASMC was studied in the $\mathrm{pH}$ range of 2-8. Effect of $\mathrm{pH}$ on $\mathrm{Cu}$ (II) ions in solution with ASC and ASMC (Fig. 4) showed that the adsorption of $\mathrm{Cu}$ (II) ions was optimum at $\mathrm{pH} 6$ with the percentage of $\mathrm{Cu}(\mathrm{II})$ ions adsorbed on ASC and ASMC by 80 and $97 \%$, respectively. At low $\mathrm{pH}$, the adsorption process is not optimal because the active groups contained in ASC and ASMC occurred protonation resulted in the binding of $\mathrm{H}^{+}$ and $\mathrm{H}_{3} \mathrm{O}^{+}$. This will reduce the availability of active groups on the adsorbent to form a complex with metals in solution [10,11].

At pH 6, the adsorption process tends to optimum. This is due to the active sites on ASC and ASMC are in the neutral

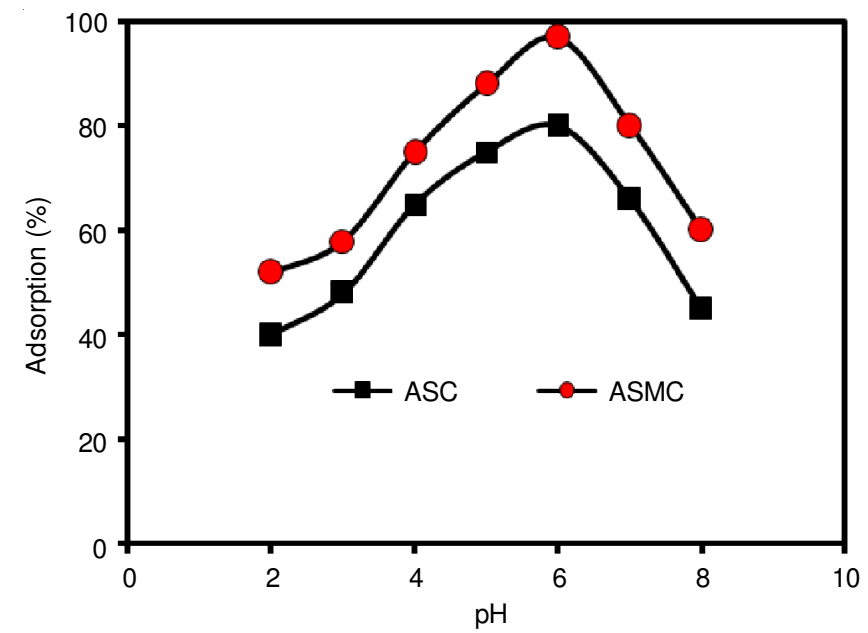

Fig. 4. Percentage adsorption of $\mathrm{Cu}(\mathrm{II})$ ion on ASC and ASMC material at $\mathrm{pH}$ interval of 2-8 (conc. $100 \mathrm{mg} \mathrm{L}^{-1}$ and temp. $27^{\circ} \mathrm{C}$ ) form as an amino, hydroxyl and carboxyl group derived from algal biomass [22-24]. Thus, these functional groups can serve as electron-pair donor and produces a strong interaction with metal ions of $\mathrm{Cu}(\mathrm{II})$. In addition, on ASC and ASMC still contained -OH (silanol) and -Si-O-Si- (siloxane) which can also act as a donor in these conditions, because it tends to negatively charged. At pH 6, the adsorption begins to decline, since $\mathrm{Cu}(\mathrm{II})$ ions started hydrolyzed to form deposited metal hydroxide species $[25,26]$.

Adsorption kinetics: Effect of interaction time of $\mathrm{Cu}(\mathrm{II})$ ion on ASC and ASMC is presented in Fig. 5. From Fig. 5, it can be seen that in general the adsorption of $\mathrm{Cu}$ (II) ion takes place relatively quickly. In first $15 \mathrm{~min}$, the adsorption increased very sharply, after $15 \mathrm{~min}$, there was a slight increase in $\mathrm{Cu}$ (II) ion adsorbed and achieve constant at $60 \mathrm{~min}$. At this stage, the adsorption process is estimated to reach equilibrium and extra time did not give rise to the amount of metal ions adsorbed significantly.

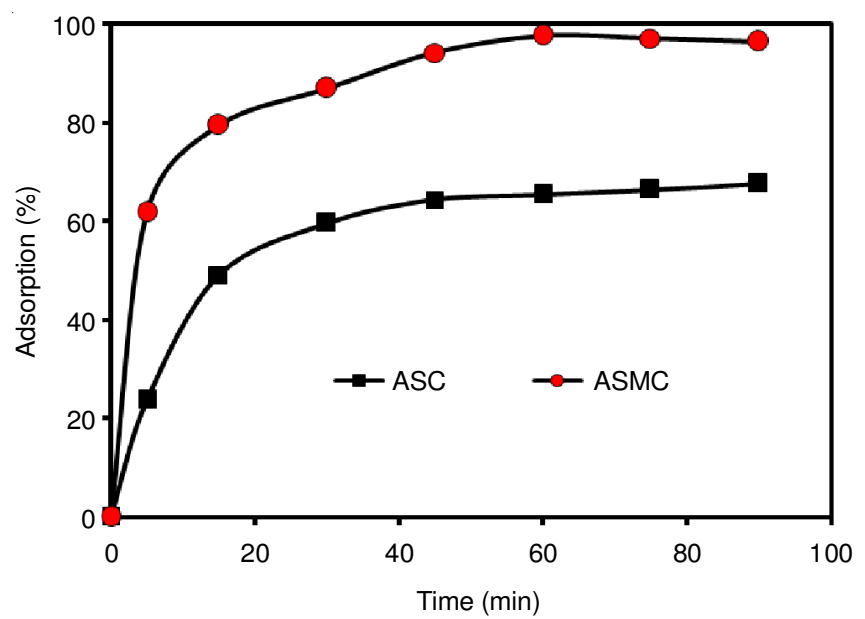

Fig. 5. Effect of interaction times versus amount of $\mathrm{Cu}(\mathrm{II})$ ion adsorbed on ASC and ASMC at pH 6 (conc. $100 \mathrm{mg} \mathrm{L}^{-1}$ and temp. $27^{\circ} \mathrm{C}$ )

The adsorption data (Fig. 5) were evaluated using pseudo first order (eqn. 2) and pseudo-second order kinetic model (eqn. 3) $[5,11,27]$ as follows:

$$
\begin{gathered}
\log \left(\mathrm{q}_{\mathrm{e}}-\mathrm{q}_{\mathrm{t}}\right)=\log \mathrm{q}_{\mathrm{t}} \frac{\mathrm{k}_{1}}{2.303} \mathrm{t} \\
\frac{\mathrm{t}}{\mathrm{q}_{\mathrm{t}}}=\frac{1}{\mathrm{k}_{2} \mathrm{q}_{\mathrm{e}}^{2}}+\frac{\mathrm{t}}{\mathrm{q}_{\mathrm{e}}}
\end{gathered}
$$

where $\mathrm{q}_{\mathrm{t}}$ and $\mathrm{q}_{\mathrm{e}}\left(\mathrm{mg} \mathrm{g}^{-1}\right)$ are the amount of metal adsorbed at time $t$ and a state of equilibrium respectively, $k_{1}$ and $k_{2}$ are the reaction rates constants of pseudo first and second order. The evaluation results with using two the kinetics models show that the adsorption kinetics models of $\mathrm{Cu}$ (II) ion on ASC and ASMC tend to follow the pseudo second-order kinetic model (Table-1).

Adsorption isotherms: The effect of initial concentration containing solution of $\mathrm{Cu}$ (II) ions to ASC and ASMC in order to determine the patterns of adsorption isotherms and adsorption parameters such as adsorption capacity and adsorption equilibrium constants. Interaction of $\mathrm{Cu}$ (II) ions at various concentrations with ASC and ASMC produce a correlation between the concentration of $\mathrm{Cu}$ (II) ion with the amount of $\mathrm{Cu}$ (II) ions adsorbed (q) on ASC and ASMC (Fig. 6). 


\begin{tabular}{clcc}
\hline \multicolumn{3}{c}{ TABLE-1 } \\
ADSORPTION KINETICS PARAMETERS OF Cu(II) IONS BY \\
THE ASC AND ASMC AT INTERACTION TIME OF 60 min, \\
INTERACTION pH OF 6, AND TEMPERATURE OF 27 ${ }^{\circ} \mathrm{C}$ \\
\hline \multicolumn{2}{c}{ Kinetics models } & \multicolumn{2}{c}{ Adsorbents } \\
\cline { 3 - 4 } & & ASC & ASMC \\
\hline \multirow{2}{*}{$\begin{array}{c}\text { Pseudo first } \\
\text { order }\end{array}$} & $\mathrm{k}_{1}\left(\mathrm{~min}^{-1}\right)$ & 0.066 & 0.087 \\
& $\mathrm{q}_{\mathrm{e}}$ cal $\left(\mathrm{mmol} \mathrm{g}^{-1}\right)$ & 0.520 & 0.550 \\
& $\mathrm{R}^{2}$ & 0.946 & 0.940 \\
\hline \multirow{2}{*}{ Pseudo } & $\mathrm{k}_{2}\left(\mathrm{~g} \mathrm{mmol}^{-1} \mathrm{~min}^{-1}\right)$ & 0.406 & 0.824 \\
second order & $\mathrm{q}_{\mathrm{e}}$ cal $\left(\mathrm{mmol} \mathrm{g}^{-1}\right)$ & 0.449 & 0.824 \\
& $\mathrm{R}^{2}$ & 0.973 & 0.988 \\
\hline
\end{tabular}

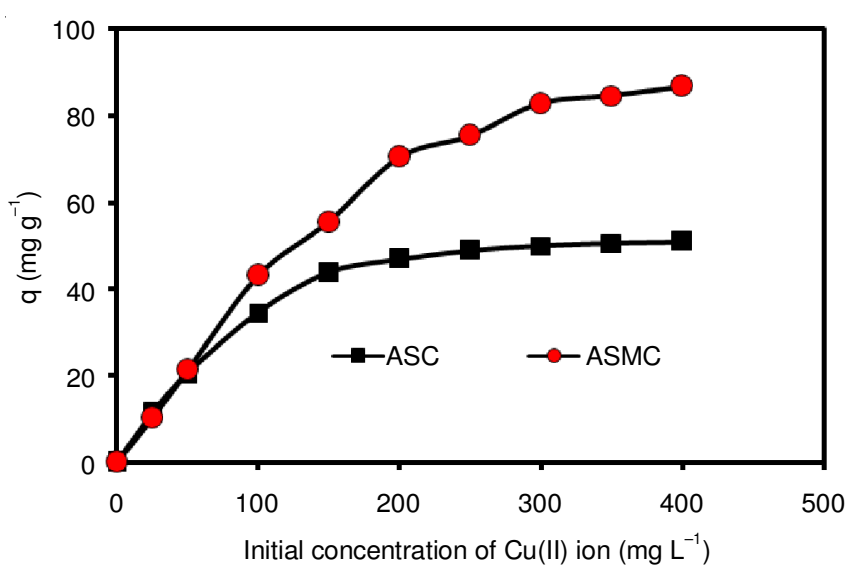

Fig. 6. Relationship between initial concentration of $\mathrm{Cu}(\mathrm{II})$ ion and amount of $\mathrm{Cu}(\mathrm{II})$ ion adsorbed (q) on ASC and $\mathrm{ASMC}(\mathrm{pH}=6$, interaction times $=60 \mathrm{~min}$ and temperature $=27^{\circ} \mathrm{C}$ )

Adsorption of $\mathrm{Cu}$ (II) ion on ASC and ASMC were evaluated by Langmuir (eqn. 4) and Freundlich adsorption isotherm models (eqn. 5) [5,11] as follows:

$$
\begin{aligned}
\frac{\mathrm{t}}{\mathrm{q}_{\mathrm{e}}} & =\frac{1}{\mathrm{q}_{\mathrm{m}} \mathrm{K}_{\mathrm{L}} \mathrm{C}_{\mathrm{e}}}+\frac{1}{\mathrm{q}_{\mathrm{m}}} \\
\log \mathrm{q}_{\mathrm{e}} & =\log \mathrm{K}_{\mathrm{f}}+\frac{1}{\mathrm{n}} \log \mathrm{C}_{\mathrm{e}}
\end{aligned}
$$

where $\mathrm{C}_{\mathrm{e}}\left(\mathrm{mg} \mathrm{L}^{-1}\right)$ is the equilibrium concentration of metal ion solution, $\mathrm{q}_{\mathrm{e}}\left(\mathrm{mg} \mathrm{g}_{-1}\right)$ is a metal ion adsorption capacity at equilibrium, $\mathrm{q}_{\mathrm{m}}$ is the monolayer adsorption capacity of adsorbent, and $\mathrm{K}_{\mathrm{L}}$ is the adsorption energy constants.

Freundlich empirical equation is an equation based on heterogeneous surfaces, where $\mathrm{K}_{\mathrm{f}}$ is the adsorption capacity factor and $\mathrm{n}$ is the intensity factor with the values of $\mathrm{n}$ ranges of 1-10 [27]. Furthermore, plot $\log \mathrm{q}_{\mathrm{e}}$ versus $\log \mathrm{C}_{\mathrm{e}}$ will produce $\mathrm{K}_{\mathrm{f}}$ and the exponent of $\mathrm{n}$. Adsorption data of $\mathrm{Cu}$ (II) ions on the adsorbent ASC and ASMC obtained from the analysis results using Langmuir and Freundlich equations is presented in Table-2.

Data regression coefficient $\left(\mathrm{R}^{2}\right)$ of adsorption isotherm model of $\mathrm{Cu}$ (II) ion by ASC and ASMC (Table-2) show that the adsorption process of these metal ions tend to follow the Langmuir adsorption isotherm model. In the Langmuir adsorption isotherm model, $\mathrm{R}^{2}$ value is closer to 1 than the Freundlich adsorption isotherm model.

Langmuir adsorption isotherm model assume that on the adsorbent surface exists a certain number of active sites which are proportional to the surface area, the adsorbent surface is

\section{TABLE-2}

ADSORPTION ISOTHERM PARAMETERS OF Cu(II) IONS ON ASC AND ASMC AT INTERACTION TIME OF $60 \mathrm{~min}$, INTERACTION pH OF 6, AND TEMPERATURE OF $27^{\circ} \mathrm{C}$

\begin{tabular}{clcc}
\hline \multirow{2}{*}{ Models } & \multirow{2}{*}{ Parameters } & \multicolumn{2}{c}{ Adsorbents } \\
\cline { 3 - 4 } & & ASC & ASMC \\
\hline \multirow{5}{*}{ Langmuir } & $\mathrm{q}_{\text {exp }}\left(\mathrm{mg} \mathrm{g}^{-1}\right)$ & 56.400 & 94.400 \\
& $\mathrm{q}_{\mathrm{m}}\left(\mathrm{mg} \mathrm{g}^{-1}\right)$ & 57.769 & 105.910 \\
& $\mathrm{~K}_{\mathrm{L}} \times 10^{-4}\left(\mathrm{~L} \mathrm{mg}^{-1}\right)$ & 3.530 & 4.236 \\
& $\mathrm{R}^{2}$ & 0.994 & 0.997 \\
\hline \multirow{3}{*}{ Freundlich } & $\mathrm{K}_{\mathrm{f}}\left(\mathrm{mg} \mathrm{g}^{-1}\right)$ & 3.548 & 6.730 \\
& $\mathrm{n}$ & 1.789 & 1.686 \\
& $\mathrm{R}^{2}$ & 0.789 & 0.670 \\
\hline
\end{tabular}

uniform and the process is monolayer adsorption [28,29]. Thus, it can be stated that the adsorption process that occurs dominated by chemical interaction between metal ions and the active sites of adsorbent.

Adsorption competition of metal ion pair (binary system): Adsorption competitions of $\mathrm{Cu}(\mathrm{II})$ ions on ASC and ASMC were studied with doing the interaction between pairs of ions $\mathrm{Cu}$ (II)/ $\mathrm{Ni}$ (II), $\mathrm{Cu}$ (II)/Zn(II), $\mathrm{Cu}$ (II)/Cd(II) and $\mathrm{Cu}$ (II)/Pb(II) in solution. These metal ions were selected based on the difference of ionic radii [30]. Besides, differences in the acidity of the metal ions tend to be acidic medium (borderline) and soft acids. From the data, competition of $\mathrm{Cu}(\mathrm{II})$ ion with ion pair of $\mathrm{Ni}(\mathrm{II})$, $\mathrm{Zn}(\mathrm{II}), \mathrm{Cd}(\mathrm{II})$ and $\mathrm{Pb}$ (II) in solution (Fig. 7) can be observed that in general ASMC adsorbent can adsorb all metal ions with fairly high percentage, although between the metal ion pairs competed have different sizes ionic radii. Differences radius of metal ions which competed in the adsorption process is one of the determining factors of the selectivity of an adsorbent to metal ions [31,32]. This indicates that the ASMC is not selective for the metal ions competed. This result was similar with Sargassum duplicatum biomass modified adsorbents with a silica matrix which is capable to adsorb $\mathrm{Pb}(\mathrm{II}), \mathrm{Cu}$ (II), and $\mathrm{Cd}(\mathrm{II})$ ions with a relatively equal adsorption capacity [33]. This is due to the interaction between metal ions and the active group of adsorbents that occur is dominated by chemical interactions through the formation of a complex between metal ions and functional groups of algae biomass that act as electron

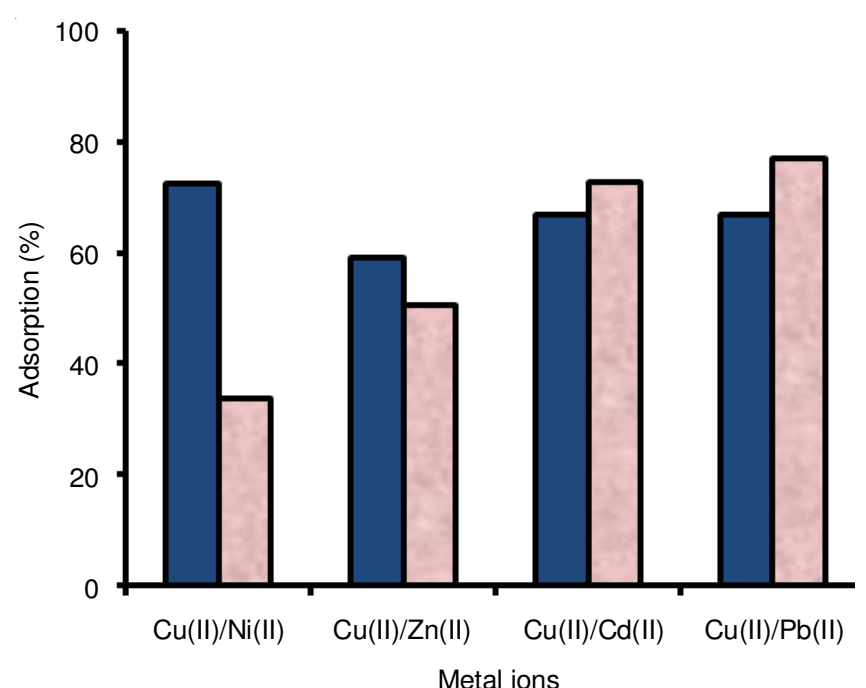

Fig. 7. Adsorption competition of $\mathrm{Cu}(\mathrm{II})$ ion to $\mathrm{Ni}(\mathrm{II}), \mathrm{Zn}(\mathrm{II}), \mathrm{Cd}(\mathrm{II})$ and $\mathrm{Pb}(\mathrm{II})$ ions on ASMC 
pair donors [34]. Thus, it can be stated that the ASMC adsorbent can be used in the treatment of waste containing a mixture of multi-component metal because it is not selective for the particular metal.

\section{Conclusion}

Modification of Chaetoceros sp. algae biomass material through the silica-magnetite coating technique has been successfully carried out and tested the adsorption ability to $\mathrm{Cu}(\mathrm{II})$ ions in solution. This material has the adsorption rate and capacity greater than algae biomass-silica hybrid material. The modified material can be used as an effective adsorbent to absorb metal ions in a multi-component mixture, because it is not selective for the particular metal.

\section{ACKNOWLEDGEMENTS}

This research was supported by the Directorate of Research and Community Services, Directorate General of Higher Education (DIKTI), Ministry of Research, Technology and Higher Education of Republic of Indonesia from the Competency Research Grant (Hibah Berbasis Kompetensi), with contract number: 79/UN26 /8/LPPM/2016. The authors would like to thank also to UPT Laboratorium Terpadu dan Sentra Inovasi Teknologi Universitas Lampung.

\section{REFERENCES}

1. R. Davarnejad and P. Panahi, J. Ind. Eng. Chem., 33, 270 (2016); https://doi.org/10.1016/j.jiec.2015.10.013.

2. M.A. Barakat, Arab. J. Chem., 4, 361 (2011); https://doi.org/10.1016/j.arabjc.2010.07.019.

3. Y.G. Bermüdez, I.L.R. Rico, O.G. Bermüdez and E. Guibal, Chem. Eng. J., 166, 122 (2011); https://doi.org/10.1016/j.cej.2010.10.038

4. K. Vijayaraghavan, M. Sathishkumar and R. Balasubramanian, Desalination, 265, 54 (2011) https://doi.org/10.1016/j.desal.2010.07.030

5. M.M. Montazer-Rahmati, P. Rabbani, A. Abdolali and A.R. Keshtkar, J. Hazard. Mater., 185, 401 (2011) https://doi.org/10.1016/j.jhazmat.2010.09.047.

6. P.O. Harris and G.J. Ramelow, Environ. Sci. Technol., 24, 220 (1990); https://doi.org/10.1021/es00072a011.

7. F. Veglio, F. Beolchini and I. Toro, Ind. Eng. Chem. Res., 37, 1107 (1998); https://doi.org/10.1021/ie9704197.

8. B. Volesky and Z.R. Holan, Biotechnol. Prog., 11, 235 (1995); https://doi.org/10.1021/bp00033a001.

9. Buhani and Suharso, Asian J. Chem., 21, 3799 (2009).

10. Buhani, Suharso and Z. Sembiring, Orient. J. Chem., 28, 271 (2012); https://doi.org/10.13005/ojc/280133.

11. Buhani, Suharso and Sumadi, Asian J. Chem., 24, 133 (2012)

12. C. Jeon, J. Ind. Eng. Chem., 17, 321 (2011); https://doi.org/10.1016/j.jiec.2011.02.033.
13. Q. Peng, Y. Liu, G. Zeng, W. Xu, C. Yang and J. Zhang, J. Hazard. Mater, 177, 676 (2010); https://doi.org/10.1016/j.jhazmat.2009.12.084

14. M.F. Desimone, C. Hélary, G. Mosser, M.-M. Giraud-Guille, J. Livage and T. Coradin, J. Mater. Chem., 20, 666 (2010); https://doi.org/10.1039/B921572G.

15. M.V. Tuttolomondo, G.S. Alvarez, M.F. Desimone and L.E. Diaz, J. Environ. Chem. Eng., 2, 131 (2014); https://doi.org/10.1016/j.jece.2013.12.003.

16. W. Jiang, X. Chen, Y. Niu and B. Pan, J. Hazard. Mater., 243, 319 (2012); https://doi.org/10.1016/j.jhazmat.2012.10.036.

17. S. Ghosh, A.Z.M. Badruddoza, K. Hidajat and M.S. Uddin, J. Environ. Chem. Eng., 1, 122 (2013); https://doi.org/10.1016/j.jece.2013.04.004.

18. M.H.P. Wondracek, A.O. Jorgetto, A.C.P. Silva, J.R. Ivassechen, J.F. Schneider, M.J. Saeki, V.A. Pedrosa, W.K. Yoshito, F. Colauto, W.A. Ortiz and G.R. Castro, Appl. Surf. Sci., 367, 533 (2016); https://doi.org/10.1016/j.apsusc.2016.01.172.

19. I. Mohmood, C.B. Lopes, I. Lopes, D.S. Tavares, A.M.V.M. Soares, A.C. Duarte, T. Trindade, I. Ahmad and E. Pereira, Sci. Total Environ., 557-558, 712 (2016); https://doi.org/10.1016/j.scitotenv.2016.03.075.

20. Y. Ren, M. Zhang and D. Zhao, Desalination, 228, 135 (2008); https://doi.org/10.1016/j.desal.2007.08.013.

21. J. Drbohlavova, R. Hrdy, V. Adam, R. Kizek, O. Schneeweiss and J. Hubalek, Sensors, 9, 2352 (2009); https://doi.org/10.3390/s90402352.

22. S. Zakhama, H. Dhaouadi and F. M'Henn, Bioresour. Technol., 102, 786 (2011) https://doi.org/10.1016/i.biortech.2010.08.107.

23. D. Bulgariu and L. Bulgariu, Bioresour. Technol., 103, 489 (2012); https://doi.org/10.1016/j.biortech.2011.10.016.

24. Y. Xiong, J. Xu, W. Shan, Z. Lou, D. Fang, S. Zang and G. Han, Bioresour. Technol., 127, 464 (2013); https://doi.org/10.1016/j.biortech.2012.09.099.

25. V.K. Gupta and A. Rastogi, J. Hazard. Mater, 152, 407 (2008); https://doi.org/10.1016/j.jhazmat.2007.07.028.

26. Y. Lin, H. Chen, K. Lin, B. Chen and C. Chiou, J. Environ. Sci., 23, 44 (2011); https://doi.org/10.1016/S1001-0742(10)60371-3.

27. Y.S. Ho, J.F. Porter and G. McKay, Water Air Soil Pollut., 141, 1 (2002); https://doi.org/10.1023/A:1021304828010.

28. X. Xin, Q. Wei, J. Yang, L. Yan, R. Feng, G. Chen, B. Du and H. Li, Chem. Eng. J., 184, 132 (2012); https://doi.org/10.1016/j.cej.2012.01.016

29. I. Larraza, M. López-Gónzalez, T. Corrales and G. Marcelo, J. Colloid Interface Sci., 385, 24 (2012); https://doi.org/10.1016/j.jcis.2012.06.050.

30. J.E. Huheey, E.A. Keiter and R.L. Keitler, Inorganic Chemistry: Principles of Structure as and Reactivity, Harper, Collins Collage Publisher, edn 4 (1993).

31. Buhani, Narsito, Nuryono, E.S. Kunarti and Suharso, Desalin. Water Treat., 55, 1240 (2015); https://doi.org/10.1080/19443994.2014.924880.

32. Buhani, Suharso and L. Aprilia, Indo. J. Chem., 12, 94 (2012).

33. Buhani, Suharso and Z. Sembiring, Indo. J. Chem., 6, 245 (2006).

34. Buhani, Rinawati, Suharso, D.P. Yuliasari and S.D. Yuwono, Desalin. Water Treat., 80, 203 (2017); https://doi.org/10.5004/dwt.2017.20932. 